\title{
THE NEW DEAL IN JAPAN - US RELATIONS? POSSIBLE IMPACT OF JAPANESE CONSTITUTIONAL REINTERPRETATION ON SECURITY COOPERATION BETWEEN THE STATES
}

\author{
Olaf Pietrzyk \\ Maria Curie-Skłodowska University in Lublin, \\ Faculty of Political Science, Department of International Relations \\ e-mail: olafpietrzyk@gmail.com
}

\begin{abstract}
The main purpose of this paper is to describe and explain security cooperation between Japan and United States from the Cold War to the present and underline the evolution of this relationship. Next issue addressed is current status of the alliance. Finally, the paper will evaluate how the recent reinterpretation of the Japanese constitution can affect the current status quo. This article is based mostly on historical approach and legal analysis.
\end{abstract}

Keywords: Japan, United States, security, Article 9 revision, collective self-defence, Self Defence Forces

It has been more than a half of century since signing "The Treaty of Mutual Cooperation and Security between the United States and Japan". Even excluding the nine years of the prior "Security Treaty Between the United States and Japan", the Japan - U.S. alliance is the longest lasting military cooperation agreement between two crucial global actors since the Peace of Westphalia - for many scholars the point defining modern system of international relations. Lasting for so long, it is understandable, that the relationship between the states has gone through many different seasons - most recent one being the ongoing redefinition of Japanese role in national security system. The main purpose of this paper is to describe and explain security cooperation between Japan and United States from the Cold War to the present and underline the evolution of this relationship. Next issue addressed is current status of the alliance. Finally, the paper will evaluate how the recent reinterpretation of the Japanese constitution can affect the current status quo. This article is based mostly on historical approach and legal analysis. It does not evaluate the issue of constitutionality of the mentioned changes, however. 


\section{JAPAN - U.S. SECURITY RELATIONS AFTER THE SECOND WORLD WAR}

To gain a better understanding of current situation we must not forget about the background of Japan - US relations. Current cooperation has its roots in World War II and its aftermath, when a defeated Japan was forced to adapt a liberal democratic framework of government. American occupation forces were stationed in Japanese between 1945 and 1951. While including the occupation period into the frames of security cooperation would certainly be a farfetched move, we cannot leave unnoticed the influence that $\mathrm{SCAP}^{1}$ and the administration under it had on the Japanese legal system. Among the most important decisions made by General McArthur's administration for security was the writing of the first draft of Japanese Constitution, which included the now so often discussed article 9, commonly known as the "Peace Clause":

\section{Aspiring sincerely to an international peace based on justice and order, the Japanese people forever renounce war as a sovereign right of the nation and the threat or use of force as means of settling international disputes. In order to accomplish the aim of the preceding paragraph, land, sea, and air forces, as well as other war potential, will never be maintained. The right of belligerency of the state will not be recognized.}

Even though article 9's meaning seems clear at first sight, it was nevertheless the subject of many later controversies. Although the law was crafted to be a guarantee to prevent remilitarisation of Japan and thus a means to strengthen American hegemony in Asia and Pacific Region, it soon became more of a curse than a blessing. After the shock defeat of the Kuomintang in the Chinese Civil War, America's regional position was suddenly greatly worsened as China, which was being tailored for the most important security partner in the region, suddenly turned the tables and drifted into a more and more anti-American Soviet bloc. These events escalated the need to re-evaluate the implications of the so called "Peace Clause". The first legal document where can observe the result of this re-evaluation is the "Security Treaty between the United States and Japan".

This Treaty, signed in San Francisco on 8 September 1951, brought a new quality into Japan - U.S. relations, and from legal point of view could even be even as their beginning. 18 April 1952 was not only a date of the treaty going into effect, but also marked the end of the American occupation. Although Japan returned to the international community as a result of the San Francisco summit, the Treaty was by no means equal in terms of alliance. As a result of Japan's demilitarisation, the Treaty was in fact more of a protection guarantee.

1 It should be noted that, contrary to the case of Germany, Japanese government institutions were not purged. Instead, they continued to exist under SCAP/GHQ supervision.

2 Government of Japan, Constitution of Japan, http://japan.kantei.go.jp/constitution_and_ government_of_japan/constitution_e.html (access: November 2015). 
In Article I it has been stated that "Japan desires, as a provisional arrangement for its defense", that:

(...) the United States of America should maintain armed forces of its own in and about Japan so as to deter armed attack upon Japan ${ }^{3}$.

As the Treaty explicitly states, the guarantee of defence is only one sided. Although the United States was obligated to defend the territory of Japan, the Japanese did not carry a similar obligation regarding the U.S. This was obviously a result of the "Peace Clause". What's interesting though, in a later part of mentioned Article I we can already notice an evolution of perception of the "Peace Clause":

Japan will itself increasingly assume responsibility for its own defense against direct and indirect aggression, always avoiding any armament which could be an offensive threat or serve other than to promote peace and security in accordance with the purposes and principles of the United Nations Charter. 4

While the "Peace Clause" explicitly states, that no army will be maintained by Japan, this part of the Treaty emphatically states than some forces will be maintained, albeit under very strict circumstances. This was largely a result of the Korean War, when both the U.S. and Japanese governments became aware that the defence of Japan would not be possible without military effort by Japan. This issue was addressed as early as late 1950 when the Japanese government, still under formal supervision of SCAP, opted for the creation of a National Police Reserve. Those forces, as well as the Coastal Safety Force, organized in the same year, while formally being police units, were in reality created to serve as a foundation for a more advanced corp. In fact, just in 1952, the year when Security Treaty took effect, the former forces were reorganised into National Safety Forces and two years later into the Self-Defence Forces, composed of both ground, air, and navy units. All those steps were taken with agreement of and even encouragement by U.S. officials. More than that, when negotiating the Treaty American officials proposed an increase of the SDF to as many as $350,000^{5}$ troops within three years, but this was rejected by Japanese side.

The Security Treaty also regulated a group of other issues. Among those was the demand that potential third powers' military presence in Japan must be agreed with Washington. This issue was covered in Article III. The subject of Article V was the process for cessation of the Treaty - the agreement was set to expire whenever in the opinion of the Governments of the United States of America and Japan there shall have come into force such United Nations arrangements or such alternative individual or collective security dispositions as

3 Ministry of Foreign Affair of Japan, Security Treaty Between the United States and Japan, http://www.state.gov/documents/organization/163490.pdf (access: November 2015).

${ }^{4}$ Ibidem.

5 R. F. Reed, The U. S. - Japan Alliance: Sharing the Burden of Defense, Washington 1983, p. 2. 
will satisfactorily provide for the maintenance by the United Nations or otherwise of international peace and security in the Japan Area ${ }^{6}$.

Perhaps the most controversial part of the Treaty was the latter part of Article I, which stated that forces may be utilized [at the express request of the Japanese Government] to put down largescale internal riots and disturbances in Japan, caused through instigation or intervention by an outside power or pow$\mathrm{ers}^{7}$. Added to the treaty, this particular part was aimed at potential steps taken by the Soviet bloc to antagonize Japanese society. Regardless of the goals, this possibility was viewed as non-democratic and subject to potential abuse able by a government willing to remove opposition obstacles. It is also worth mentioning that U. S. was not obligated to intervene in the case of internal turmoil. Another issue that raised a lot of doubts was the "Administrative Agreement" that was signed by both states without need for ratification either government. While the Treaty itself was relatively short, this Agreement was far larger and included a large number of regulations that fundamentally affected the terms of alliance. The primary example would be Article XVII that granted Americans jurisdiction over all U.S. military personnel who committed crimes on the territory of Japan.

The Treaty had been the foundation of Japan - U.S. relations for almost 10 years and its main issues were confirmed and extended by aforementioned "U.S. and Japan Mutual Defense Assistance Agreement in 1954". As time passed, the Japanese SDF structure had grown more and more stable. Japanese public opinion also was not too fond of a treaty that was result of negotiations between occupied and occupying states. As a result, in 1959 both sides agreed to revisit the agreement, a process that was concluded in January 1960 with the signing new "Treaty of Mutual Cooperation and Security between the United States and Japan".

\section{TREATY OF MUTUAL COOPERATION AND SECURITY BETWEEN THE UNITED STATES AND JAPAN}

The revision of the alliance between the two powers was no easy task. Revision of the terms of cooperation was perceived as outright action against the "Peace Clause". Left wing voters, mostly connected with Socialist Party and trade unions, protested both against rearmament and alliance with the U.S. as whole. On contrary, right wing Prime Minister Kishi Nobusuke saw in the revision a chance to increase the international position of Japan. The ratification of the treaty in the U.S. was done on 19 January 1960. The document was first put to debate in Tokyo on 9 February, but because of Socialist and Communist resistance, the ratifica-

${ }^{6}$ Ministry of Foreign Affair of Japan, Security Treaty Between the United States and Japan, http://www.state.gov/documents/organization/163490.pdf (access: November 2015). Ibidem.

7 Ibidem. 
tion process was halted until 20 May, when the treaty was approved by House of Representatives. Before voting in the House of Councillors, however, Japan Socialist Party members tried to prevent LPD deputes from entering the parliament building, but they were later removed by the police. As a result, Japan saw one of biggest strikes in its modern history one that involved more than $6.2 \mathrm{~m}$ people ${ }^{8}$. Although the voting was halted, the Treaty became effective automatically thirty days after approval by the lower house of parliament. The turmoil over ratification also led to the resignation of Prime Minister Kishi and his government.

The new Treaty kept the fundamental principles of the 1952 agreement. The defence obligation in Article 5 still differed from the usual form which we would expect to see in defence treaties. It states:

Each Party recognizes that an armed attack against either Party in the territories under the administration of Japan would be dangerous to its own peace and safety and declares that it would act to meet the common danger in accordance with its constitutional provisions and processes ${ }^{9}$.

The most noticeable change from the previous Treaty is the scale of defence. Although the alliance's reach was still effectively reduced to the territory of Japan and the Japanese side could only provide reduced means of its application, a result of restrictions provided by Article 9 of Japanese Constitution, the Treaty was no longer a one-sided guarantee of protection. Japan was also obligated to protect U.S. facilities on its territory. This allows us to assume that Treaty of Mutual Cooperation and Security should be viewed as an agreement between two equal states, which was notable progress compared to previous document. It should also be noticed that Article 9 created an empty void in terms of security cooperation at the Ryukyu Islands, which at the time of treaty ratification were under $\mathrm{U}$. S. administration. Another important change appears in Article X, which states that after the treaty remains in force for ten years, one side may inform the other about its desire to terminate cooperation. The termination provision was much different than in the former Treaty, which was supposed to last as long as parties find it appropriate.

Article VI of the Treaty sanctioned a U. S. military presence in Japan by a "Status of Force Agreement". As with the 1952 treaty, the direct status of U.S. armed forces as well as usage of facilities and areas were to be regulated by separate document. A "U.S.-Japan Status of Forces Agreement" was signed in the same year and addressed a number of controversial issues that had been included in a previous document of this kind. Perhaps the most important point for Japanese society was the issue of court system jurisdiction for U.S. military and civilian

8 J. Jesty, Tokyo 1960: Days of Rage \& Grief, http://ocw.mit.edu/ans7870/21f/21f.027/tokyo_1960/anp2_essay01.html (access: November 2015).

9 Ministry of Foreign Affair of Japan, Security Treaty Between the United States and Japan, http://www.mofa.go.jp/region/n-america/us/q\&a/ref/1.html (access: November 2015). 
personnel, which was transferred in most cases to the Japanese legal system. There are two exceptions from this rule however: whenever the crime was committed by a soldier acting on duty or whenever a victim was an American citizen as well ${ }^{10}$. The Agreement also states that areas used by U.S. military personnel were to be returned to Japan when they were no longer needed and shall be used taking this issue into consideration. Any return of military areas would need to be approved by both governments. American citizens working is such areas and facilities were also to be excluded from visa procedure.

Other articles of new Treaty regulate standard issues we would expect of treaties of this type. In Article I the parties promised to refrain from the use of force until necessary and promised to resolve conflicts in peaceful manner whenever possible. In Article II both parties express the will to increase cooperation in developing peaceful and friendly international relations as well as economic cooperation. In Article III both sides obligate themselves to increase their defensive capabilities. Article IV contains mutual expression of will to host consultations the threat to peace of Japan or the Far East region occurs as well as "from time to time." Article VII was expressing the compatibility of the Treaty with the Charter of the United Nations, and Article VIII set the framework for the document to enter into force. This would happen when the instruments of ratification were changed by the parties in Tokyo. Article IX set the framework for the expiry of the previous security treaty.

The signing of the Treaty of Mutual Cooperation and Security between the United States and Japan was undoubtedly a step forwards for Japan - U.S security cooperation. It cleared away many of the issues and grey areas that were either absent or unaddressed in the 1952 agreement. The renewed treaty was clearly a pact between two independent sides, something that could be questioned in the previous agreement. Its effect was still limited by the "Peace Clause" and reached only the borders of the Japanese state. Nonetheless, the Treaty continues to serve as a foundation for security cooperation to the present day, being renewed every five or ten years.

The treaty has never been officially reviewed, but that does not mean its understanding has remained constant through last 55 years. Although the text of document remained the same, its reach and, especially, the responsibility of the Japanese side grew over time. The Japanese military made great progress during the 1960-1980 period. At the beginning of this period, the SDF was considered incapable of any complicated military actions. This situation started to change with Richard Nixon's 1969 "Guam Doctrine" that placed greater responsibility for security on allied Asian states. 1972 saw the return of Okinawa to Japan as well as the publication of the first "Defense White Paper". Four years later, a bilateral Security Consultative Committee was established. In the same year Japan released

${ }^{10}$ In reality this system did not work well, as U.S. military authorities were reluctant to allow Japanese prosecutors to have contact with culprits. This usually resulted in an inability to proceed with a trial. 
its "National Defense Program" guidelines which connected with planned reform of SDF. Two years later both parties signed "Defense Guidelines," which regulated actions taken by both sides during potential crises. This sudden invigoration of defence cooperation occurred as Japanese economic growth that that allowed for military spending to reach a level of $1 \%$ yearly GDP.

\section{BEYOND THE COLD WAR}

The end of the Cold War has brought great change to international system as whole as well as Japan - U. S. security cooperation. The first test to the Japanese role in the new global system appeared as early as 1990 during the Gulf War. Despite providing large financial support for both the intervention and later stabilization processes, Japan was accused of not taking enough responsibility for world security and gained the media nickname of "Checkbook Power". As a response, in 1992 Japanese Diet voted in favour of the International Peace Cooperation Law, which allowed Japanese military personnel to participate in UN peacekeeping operations ${ }^{11}$.

The two sides agreed in 1996 to review the previous defence guidelines, a review that eventually occurred in 1997 . The reason behind this revamp was the evolution of security challenges after the end of Cold War. One of most noticeable changes included in the document was redirecting the main purpose of cooperation from the defence of Japanese territories to regional security. For this purpose, the parties created the conception of "Situation in Areas Surrounding Japan," in which Japanese agencies would be granted limited possibility of action to support American forces. Although it was never directly stated, it is suspected that this area would include the Korean Peninsula and the Taiwan Strait ${ }^{12}$ as tensions in those areas were one of main reasons behind the revision. Another change brought was expanding the permissions for use of Japanese military facilities by U. S. troops in the times of potential crisis. Finally, the revamped guidelines established the Bilateral Coordination Mechanism, a coordinating body that would become active in circumstances covered by "Situation in Areas Surrounding Japan" as well as a direct attack on Japan.

The next de facto revisions would come as a response to the terrorist attacks of 9/11. To create the legal possibility for marine support of U.S. operations in Afghanistan, Japan enacted "Special Measures Law for Anti-Terrorism". Three years later Japan's engagement was even greater. In 2004 Prime Minister Koi-

${ }^{11}$ Japanese civilian personel was a part of UN operations since 1989 when it took part in United Nations Transition Assistance Group (UNTAG) in Namibia.

${ }^{12}$ S. Takahashi, Upgrading the Japan-U.S. Defense Guidelines: Toward a New Phase of Operational Coordination, p. 7, https://project2049.net/documents/japan_us_defense_guidelines_ takahashi.pdf (access: November 2015). 
zumi's cabinet passed the Special Measures Law for Iraq Reconstruction, which allowed for the dispatch SDF troops to Iraq. Although the direct effects of this mission were somewhat questionable and Prime Minister Junichiro Koizumi suffered a noticeable loss of public approval, the sole fact of dispatching SDF to Iraq had a positive impact on strengthening Japan - U.S. trust and their capabilities for cooperation. Eventually, ground SDF forces would finish their mission in 2006 and the air force two years later.

2004 also saw the publication of a new National Defense Program Guides. This document set the following priorities for Japan's security policy: to prevent any threat from reaching Japan and, in the event that it does, repel it and minimize any damage and to improve the international security environment so as to reduce the chances that any threat will reach Japan in the first place. Those goals were to be achieved by, among other means, further developing close cooperative relationship with the United States, based on the Japan-U.S. Security Arrangements ${ }^{13}$. The guidelines also set plans for further developing of the SDF but only under the guidelines of Japanese Constitution and maintaining civilian control over the forces. Furthermore, the document stated that Japan will proactively engage in strategic dialogue with the United States on wide-ranging security issues such as role-sharing between the two countries and U.S. military posture, including the structure of U.S. forces in Japan, while working to harmonize our perceptions of the new security environment and appropriate strategic objectives ${ }^{14}$. Following years saw further development of security cooperation between the states. The result of it was signing Common Strategic Objectives and The Japan-US Alliance: Transformation and Realignment for the Future in 2005 and further cooperation on a ballistic defence program.

Further development of relations was halted by internal political change in Japan. After end of Koizumi era only Shinzo Abe's first term could be perceived as a step forward in security cooperation. Abe managed to raise Defence Agency to the rank of ministry, but his other security-related efforts, including, for example, authorization to use SDF troops abroad without UN resolution, turned out to be complete fiasco. LPD then lost the 2007 elections to the upper house of parliament, which effectively halted any possible efforts of Fukuda and Aso governments, and then suffered another loss in the 2009 elections to the lower house that effectively removed LDP from power.

2009 saw government shifts in both Japan and the United States. Barack Obama's administration sought to continue deepening cooperation with Japan, but the new DPJ government of Prime Minister Yukio Hatoyama came to power largely due to opposition to further militarisation. Japanese society at that time was largely annoyed by constant Okinawa base issues and the reigniting of the

${ }^{13}$ Ministry of Defense, NATIONAL DEFENSE PROGRAM GUIDELINES, FY 2005-, http:// www.mod.go.jp/e/d_act/d_policy/pdf/national_guidelines.pdf (access: November 2015).

${ }^{14}$ Ibidem. 
North Korea issue by the George W. Bush Administration. There was also a loud voice calling for encouraging Asian cooperation, possibly at the cost of lowering the priority of Japan - U.S. ties. Cooperation between the two sides could not possibly have a worse start as the U.S. pressed for progress on the Futenma Base Relocation on Okinawa. Hatoyama had openly opposed that move during the campaign, but eventually had to agree to U.S. demands. This also resulted in his dismissa ${ }^{15}$ and the creation of a new cabinet under Naoto Kan. Kan and his successor Yoshihiko Noda saw direct improvement in relations between the states. This was caused by increased tensions with China over the Senkaku Islands and another period of aggressive policy by North Korea caused by ongoing power succession there. Another reason for closer ties was the U. S. Army's assistance during and after the Great Tohoku Earthquake of September 2011 which resulted in a great improvement of Japanese opinion in regards of American military personnel ${ }^{16}$. The popularity boost greatly affected greatly the SDF. On the contrary, the DPJ government's reaction to the disaster was viewed as insufficient and turned out to be one of main reasons behind the LPD's return to power in year 2012.

\section{JAPAN U. S SECURITY RELATIONS DURING SHINZO ABE SECOND TERM}

Shinzo Abe, who was elected on his second term in the 2012 elections, was a strong supporter of Japan - U.S. security cooperation as well as strengthening Japan's military potential in general. To date, he has more than lived up to those expectations. Although the LPD's recent election victories were due mostly to the hope for successful implementation of an economic revival program popularly called Abenomics, thanks to regaining majorities in both houses of the Japanese Parliament Abe is able to constantly push forward security related issues as well. During his first term, in 2007, he created the "Advisory Panel on Reconstruction of the Legal Basis for Security" - a body that was assigned the task of reviewing security matters in the current legal system to see if they fit the current international situation. Because of a shortage of time, the Panel did not have much of an impact in 2007. Abe did not forget this idea, however, and he revived the group at the beginning of 2013. After almost a year and a half the Panel finished its work and published the "Report of the Advisory Panel on Reconstruction of the Legal Basis for Security"17. It argued that the current interpretation of Article 9 does not

${ }^{15}$ „The Guardian”, Japan 's prime minister Yukio Hatoyama resigns, 02.07.2010, http://www. theguardian.com/world/2010/jun/02/japan-prime-minister-yukio-hatoyama-resigns.

16 "The Japan Times", E. Johnston, Operation Tomodachi a huge success, but was it a oneoff?, http://www.japantimes.co.jp/news/2012/03/03/national/operation-tomodachi-a-huge-success-but-was-it-a-one-off/\#.V187AHarSUk.

${ }_{17}$ The Advisory Panel on Reconstruction of the Legal Basis for Security, Report of the Advisory Panel on Reconstruction of the Legal Basis for Security, May 15, 2014, https://www.kantei. go.jp/jp/singi/anzenhosyou2/dai7/houkoku_en.pdf. 
fit current state of international system as it is based on early 20th century idealism. The document does not advise abandoning the "Peace Clause" however. On the contrary, the authors argue that pacifism should remain one of main principles behind the policy of the Japanese state. They do advise reinterpretation of Article 9, however, to include base rights of states that have been acknowledged by U.N. Charter with special focus on the right to Collective Self-Defence. The reasons behind the possibility of an actual reinterpretations are the following: 1) Article 9 was de facto constantly being reinterpreted before 2) the reinterpretation itself is essential for successful protection of human rights that were expressed in Constitution Preamble's and Article 13 3) the change in the nature of security challenges to regional and cross-border threats that have made the previous understanding obsolete. According to the document, Article 9 should be reinterpreted as follows:

Paragraph 1 of Article 9 should be interpreted as prohibiting the threat or the use of force as means of settling international disputes to which Japan is a party. The provisions should be interpreted as not prohibiting the use of force for the purpose of selfdefense, nor imposing any constitutional restrictions on activities that are consistent with international law. The provision of the paragraph 2 of Article 9 should be interpreted as stipulating that "in order to accomplish the aim of the preceding paragraph," war potential will never be maintained. The paragraph should therefore be interpreted as not prohibiting the maintenance of force for other purposes, namely self-defense or socalled international contributions to international efforts. ${ }^{18}$

The reinterpretation proposed by the Advisory Panel fundamentally changes the meaning of Article 9. It would essentially make the competencies of Japan's SDF equal or close to equal to the armies of other states following the U. N. charter. Reinterpretation of the second paragraph could be perceived as less wide than the first, as it could be seen as renouncing the possibility of maintaining strictly offensive types of weaponry. This also however was not directly stated in the document.

Apart from the Article 9 reinterpretation Panel has also reviewed possible reinterpretations connected with other issues as well as other laws. Among those are the previously mentioned problems of collective self-defence. The authors argue that a reinterpreted Article 9 does allow collective self-defence to be possible for the same reason and by the same means as it allows self-defence as whole. Another argument behind the decision was that collective self-defence is not included in the "use of force" as means of settling international disputes to which Japan is a party ${ }^{19}$ and therefore it should be allowed. They do note, though, that the actions should be taken only after a direct request from an allied power. The same logic was applied to the case of U. N. entailing military measures. The so called "Ittaika" principle, which disallowed Japanese troops to take actions

${ }^{18}$ Ibidem. P. 48

${ }^{19}$ Government of Japan, Constitution of Japan, http://japan.kantei.go.jp/constitution_and government_of_japan/constitution_e.html (access: November 2015). 
that might lead to or be a part of the use of force, was also recommended for abandonment. The reason was that times this concept was previously used, for example the previously mentioned U. N missions, would be excluded from the "use of force" category by the new Article 9 interpretation.

We did not have to wait long for Abe's response the report. On 1 July 2014 Japanese Government published Cabinet Decision on Development of Seamless Security Legislation to Ensure Japan's Survival and Protect its People ${ }^{20}$. This document was crafted to serve as a foundation for further legislation on the matter of security and relied largely on the effort of the Panel, although it didn't adopt all of its ideas. Abe and his ministers focussed on three issues:

1) Response to an Infringement that Does Not Amount to an Armed Attack - main purpose of proposed changes is to create a legal framework to deal with issues that have largely emerged after creation of SDF forces and thus remained in a legal grey zone, for example hybrid wars. Japan government goal is to prepare legal measures to deal with those issues with reviewing, coordinating and planning actions of SDF, police organizations and government agencies. What's more important, at least in regards to the issue of Japan - U. S. cooperation, is the announcement about developing legislation that would allow SDF forces to support U. S. Army with "limited weapon use" while said forces are carrying out the tasks which contribute in defense of Japan. While this change might not seem as important at first, we need to look at it from a broader context which as stated in the document's preamble: any threats, irrespective of where they originate in the world, could have a direct influence on the security of Japan ${ }^{21}$.

2) Further Contributions to the Peace and Stability of the International Community - Japan government opts to review the capabilities of SFD in this matter as well, although the changes again are not as radical as proposed by the Panel. The Abe government has opted to not completely abandon the concept of "Ittaika" but rather to change its form. The main difference is previous interpretations allowed Japanese SDF forces to be deployed only in "rear" and "no combat" zones when no fighting is supposed to take place. The new one, however allows SDF to perform its backup and supply duties in every area where combat is not currently taking place. Another issue that is planned to be reviewed is the possibility of using weapons during U. N. peacekeeping missions or tasks that aim to rescue Japanese citizens whose lives are in danger. The future regulations are to allow SFD to perform such tasks as long as they are approved by the local government or in the case of peacekeeping missions by all sides on conflict.

${ }^{20}$ Ministry of Foreign Affairs of Japan, Cabinet Decision on Development of Seamless Security Legislation to Ensure Japan's Survival and Protect its People, http://www.mofa.go.jp/fp/nsp/ page23e_000273.html.

${ }^{21}$ Ibidem. 
3) Measures for Self-Defense Permitted under Article 9 of the Constitution - As stated, Abe's government found previous interpretations of the constitution insufficient to serve as a foundation for legislation system that could successfully face current security challenges. Again, as in the case Report of the Advisory Panel, the legal basis for reinterpretation of the "Peace Clause" was largely rooted in government responsibilities stated in Article 13. Those included "their [the people's] right to life, liberty, and the pursuit of happiness ${ }^{22}$ " and, according to Abe, cannot be protected with one-sided renunciation of the "use of force" including the right to self-defence. As such, at the "absolute minimum," Article 9 has to permit Japan the use of force so the government can carry out the responsibilities mentioned in article 13. This interpretation also includes a right to collective self-defence. The explanation behind it is again connected with the intensification of international relations - an attack on Japan close allies would also pose direct threat to security of Japan, itself, and thus preventing or confronting it should be considered as an act of self-defence. It is, however, understood that those actions should never go against international law or the Japanese Constitution and be under strict democratic control of Japanese Society.

The government's recommendations were approved by lower house of the Diet on 15 July 2015 and by the upper house on 17 September 2015. The approval process itself was the subject of large controversies as it was judged by some to be an unconstitutional way to enforce fundamental change of the legal system. Opposition parties tried unsuccessfully to forcibly block the legislative process in upper house. Society opposition was also vocal. Both the issue and way of handling it by the Abe government were largely perceived as unconstitutional. The initial push for the legislation resulted in a fall of approval of Abe government from $57 \%$ to $48 \%$. Support for the reinterpretation of Article 9 was even lower - initially $51 \%$ of Japanese citizens were against the changes and only $36 \%$ expressed their support for this current policy. Opinion trends seemed to change in favour of Abe government as in August approval of his government rose above $50 \%$ again $^{23}$. This, however, does not affect the disapproval of the revisions. More than that, recent polls have also shown that over $80 \%$ feel they haven't been informed well enough on this matter. Regardless of lack of social approval, Prime Minister Abe still opted to revise the "Japan - U.S. Guidelines for Defense Cooperation" at the end of this year and to do so with taking account the mentioned reinterpretation. "National Defence Guidelines" were updated on

${ }^{22}$ Government of Japan, Constitution of Japan, http://japan.kantei.go.jp/constitution_and_ government_of_japan/constitution_e.html (access: November 2015).

${ }^{23} \mathrm{~K}$. Matake, Japanese Public Opinions about the Exercise of the Right of Collective Self-Defense, http://www.japanpolicyforum.jp/archives/politics/pt20140925231907.html (access: November 2015). 
13 December 2013, even before the revision itself, but were made with regard to upcoming changes and thus will probably not need to be adapted.

\section{WHAT IS THE FUTURE OF JAPAN - U.S. SECURITY COOPERATION?}

Recent Japanese actions undoubtedly brought a new quality to relations between the two allies. Although the main reason behind regulating the issue of non-war actions was clearly the friction around the Senkaku Isles, the regulations will also increase the capabilities of SFD forces to deal with terrorism related issues around the world, thanks to an acknowledgement of the collective selfdefence concept. The new interpretation stresses that those actions should be taken with "minimal needed use of force" but we still have to wait how to see or if this barrier will be regulated by Japanese law. While enchanting capabilities of Japanese involvement in U.N. peacekeeping operations do not directly influence the U.S.-Japanese alliance, they should nevertheless be perceived as positive sign. We have to remember that U.S. often takes a role of inspirer and coordinator for this type of action. Because of this, these changes may have a positive impact on bilateral security relations if a situation similar to Iraq's stabilization mission ever occurs again. Finally, the reinterpretation of the Article 9 approach to the issue of self-defence is without a doubt one the most important improvements for the alliance since the creation of the SDF. Because of this, the Japanese military may not only provide limited combat support to U.S. but also other states Japan is closely tied to. And those also happen to be America allies. The new measures provided by this reinterpretation are to be very limited and under strict control, but taking into consideration the history of expanding limits on the Japan military, further liberalization of the rules would not be a surprise to anyone.

The Treaty of Mutual Cooperation and Security between the United States and Japan will not become obsolete any time soon. Although recent changes by the Abe government leave room for improvements in bilateral security cooperation, especially at the level of geographic range affected by the alliance, no new treaty will be needed to implement them. Instead, we can expect to revision of lower level documents regulating affected issues. This includes the previously mentioned revision of the "Japan - U.S. Guidelines for Defence Cooperation".

Although Shinzo Abe's tirelessly pushing to increase the level of cooperation may suggest inevitability in further changes, there are certain problems with this approach. As mentioned, recent Cabinet decisions are largely unpopular and viewed as unconstitutional. Thus, without proper campaign and debate, rushing further changes might cost Abe and the LPD election victories, repeating the mistakes of Koizumi and Abe's own first term. It should however be expected that Prime Minister Abe will take into consideration the implications of both past efforts and the unpopularity of his recent push. Changes have yet to be made to implement the new laws. This period of implementation might as well be used to win the support 
of society. Even if that does not happen and the LPD loses the Cabinet, reversion of the revisions is very unlikely. As in 2009, when the DPJ did not reverse the changes made by Koizumi, any government shift will probably not see the return to "pre-Abe" interpretation. Although halting future changes might occur, the security cooperation would be likely to continue to progress on current legal terms.

Japan - U.S. security cooperation is expected to steadily improve in long term regardless of the government in both states. This is largely a result of similar defence priorities in both Washington and Tokyo. Common challenges include the rise of China that openly question Japan supremacy over Senkaku isles as well as current global system that Beijing finds as U.S. centred. Although China's economic growth has recently shown symptoms of a slowdown it is unlikely that it will affect its military spending. This increase of army funding is actually working in favour of U.S. Japan alliance as it increases the distrust of Japanese side and led to an increase in Tokyo's military budget. Although North Korea seems to be past its succession crisis and has calmed its rhetoric a bit, it is doubtful that anyone perceives that as a permanent change. Both sides will continue to view Pyongyang as a potential threat and work towards the common goal of minimizing it. There are other issues as well. Perhaps the biggest irony is that the more proactive Japanese course has created more tensions with another U.S. ally, the Republic of Korea. It should be a priority for both sides to mend bilateral relations to minimize this distrust, however this will be a long process. Tensions around American troops stationed in Okinawa are another issue that needs to be addressed. While not as violent as before, the recent escalation that occurred at the end of October 2015 shows that this issue still undermines the trust of Japanese society in their American allies. Mentioned issues may however only slow down a process of further deepening of security cooperation between both states. Recent changes are too significant to reverse, and they should be taken only as prelude of more intense security cooperation that is bound to happen in not so distant future.

\title{
NOWY ETAP W STOSUNKACH JAPOŃSKO-AMERYKAŃSKICH? REINTERPRETACJA \\ KONSTYTUCJI JAPONII I JEJ KONSEKWENCJE JAPOŃSKO-AMERYKAŃSKĄ WSPÓŁPRACĘ W OBSZARZE BEZPIECZEŃSTWA
}

\begin{abstract}
Abstrakt. Głównym celem artykułu jest analiza współpracy w dziedzinie bezpieczeństwa pomiędzy Japonią a Stanami Zjednoczonymi od Zimnej Wojny do chwili obecnej, a szczególnie uchwycenie ewolucji i dynamiki tej współpracy. Szczegółowej analizie poddany został obecny status sojuszu pomiędzy państwami. Istotne jest również ukazanie procesu, którego celem jest reinterpretacja japońskiej konstytucji oraz tego jak może to wpłynąć na obecny stan stosunków pomiędzy państwami. Poniższy artykuł bazuje przede wszystkim na analizie historycznej oraz analizie aktów prawnych.
\end{abstract}

Słowa kluczowe: Japonia, Stany Zjednoczone, bezpieczeństwo, konstytucja Japonii, zbiorowa samoobrona, Siły Samoobrony 